\title{
圧力変動計測による極低温インデューサに発生するキャビテーションの観察
}

\section{Observation of cavitation in cryogenic inducer based on unsteady pressure measurements}

\author{
○菊田 研吾（東北大・院） 長谷川 敏（JAXA） 正員 島垣 满（JAXA） \\ 中村 憲明（科学技術振興事業団） 正員 徳增 崇（東北大） 正員 吉田 義樹（JAXA）
}

\begin{abstract}
Kengo KIKUTA, 2-1-1, Katahira, Aoba, Sendai, Miyagi ,980-0812
Satoshi HASEGAWA, i Koganezawa, Kimigaya, Kakuda, Miyagi, 981-1525

Mitsuru SHIMAGAKI, 1 Koganezawa, Kimigaya, Kakuda, Miyagi, 981-1525

Noriaki NAKAMURA, 1 Koganezawa, Kimigaya, Kakuda, Miyagi, 981-1525

Takashi TOKUMASU, 2-1-1, Katahira, Aoba, Sendai, Miyagi, 980-0812

Yoshiki YOSHIDA, 1 Koganezawa, Kimigaya, Kakuda, Miyagi, 981-1525
\end{abstract}

\begin{abstract}
For experimentally investigation of thermodynamic effect on cavitation, it is of value to observe the cavitation in cryogenic flow, but the visualization is difficult. For this reason, we tried to estimate the cavitating region in liquid nitrogen based on unsteady pressure distribution. Unsteady pressure was measured by placing sensors on casing of inducer. By this method, it succeeded in grasping of the cavitating region in relation to cavitation number.

The comparison of the experiments in liquid nitrogen and in cold water allowed us to estimate the amplitude of the thermodynamic effect. Consequently, it turns out that the amplitude of thermodynamic effect is changing with the cavity length. The amount of temperature depression increases rapidly when the cavity extends over the throat.
\end{abstract}

Key Words: Inducer, Cavitation, Thermodynamic effect, Unsteady pressure

\section{1. 粕带}

ポンプにおける熱力学的効果の推定は, Stepanoff ${ }^{(1)}$ 以来, 主に揚程低下点の比較を基に行われている.しかし，この方 法だけではキャビテーションの発生状況に関する情報は無 く，そのメカニズムについてはよく分かっていない. そこで 本研究ではインデューサ内部のキャビテーションの発生状 況に着目する.インデューサのケーシングに変動圧センサを 設置し, 測定された変動圧の分布よりキャビティ長さを推定 する方法 ${ }^{(2)}$ を試みた。この実験方法で得られたキャビティ長 さを用いて, キャビテーションの発生と熱力学的効果との関 俰について調べた.

\section{2. キャビティ長さと温度降下}

図 1 はキャビテーション数に対してキャビティの長さ $C_{c l}$ をプロットしたものである. 水試験のキャビティ長さ赤丸 (○) と窒素試験のキャビティ長さ緑丸（○）を比べると, 窒 素試験の方が短くなっており, 熱力学的効果がキャビティの 長さの差となって現れていることが分かる.

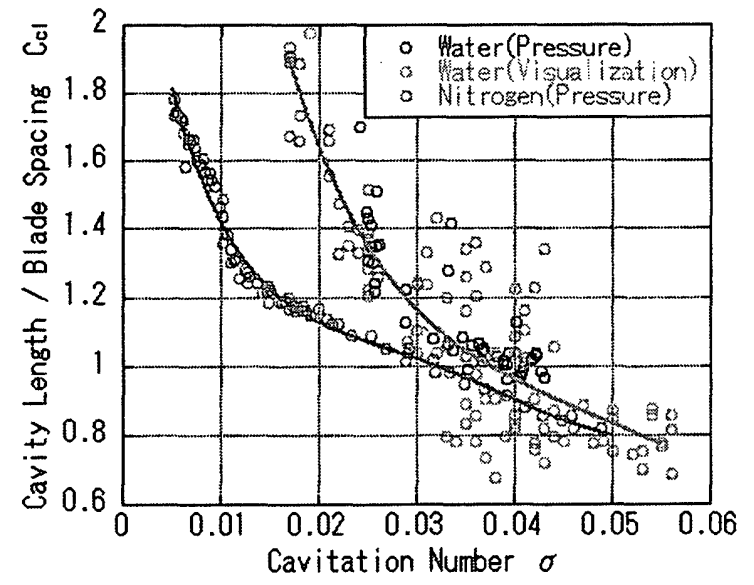

Fig. 1 Variation of the cavity length with the cavitation number for cold water and for liquid nitrogen

図 2 は, 図 1 を基にキャビティ長さに対しての温度の降下 量の変化を示したものである. Franc ら ${ }^{(3)}$ の実験においても,
温度降下の大きさがキャビティ長さに応じて増大する傾向 が示されているが, 今回の翼端キャビテーションをパラメー タにした場合とはその傾向が異なる. 本実験では, キャビ ティがスロートに入ると $\left(C_{c l}=1.0 \sim 1.2\right)$ 温度降下 $\Delta T$ は急 激に大きくなっている.

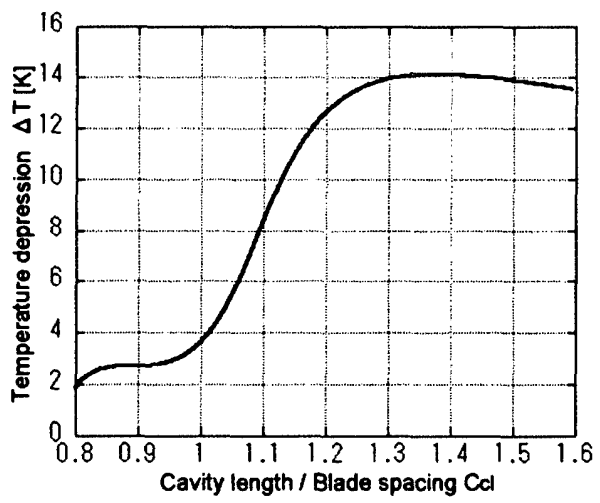

Fig. 2 Estimated temperature depression as a function of the cavity length for the inducer working in liquid nitrogen (80K)

\section{3. 結志}

液体窒素 $(80 \mathrm{~K})$ 中のインデューサの翼間の 8 箇所での変動 圧の測定を行った．その测定結果を基に，インデューサ翼端 に発生するキャビテーションの領域を推定し, キャビティ長 さを求めた. 水試験における可視化観察のキャビティ長さと の比較から, キャビティ長さに対する温度降下量 $\Delta T$ の変化 の様子を求めた.これより, 熱力学的効果の影響の大きさは キャビティの長さによって変化しており, その変化の様子は 一様ではなく, キャビティが翼間に達するあたりで大幅に増 加し, それ以降では一定となるような傾向を持つ事が分かっ た.

\section{参考文献}

(1) Stahl, 'H. A., Stepanoff, A. J., Trans. ASME, Ser. A, 78 (1956), 1691-1693.

(2) 前川康和・ほか 3 名, 機論, 63-605, (1997), 132-138

(3) Franc, J. P. ・ほか 2 名, CAV2003, (2003), CAV03-GS-16-001 